\title{
Articulations of Islamophobia: From the Extreme to the Mainstream?
}

\author{
Aurelien Mondon ${ }^{1}$ \\ Department of Politics, Languages \& International Studies, University of Bath, Bath, UK
}

Aaron Winter

Criminology, University of East London, London, UK

\section{ABSTRACT}

This article examines the construction, functions and relationship between the diverse and changing articulations of Islamophobia. The aim is to contribute to debates about the definition of Islamophobia, which have tended to be contextually specific, fixed and/or polarized between racism and religious prejudice, between extreme and mainstream, state and non-state versions, or undifferentiated, and offer a more nuanced framework to: (a) delineate articulations of Islamophobia as opposed to precise types and categories; (b) highlight the porosity in the discourse between extreme articulations widely condemned in the mainstream, and normalized and insidious ones, which the former tend to render more acceptable in comparison; (c) map where these intersect in response to events, historical and political conditions and new ideological forces and imperatives; and (d) compare these articulations of Islamophobia in two contexts, France and the United States.

KEY WORDS: Islamophobia; Anti-Muslim Racism; Liberalism; France; United States; Terrorism

\footnotetext{
1 Aurelien Mondon. email: a.mondon@bath.ac.uk, twitter: @aurelmondon, university profile: http://www.bath.ac.uk/polis/staff/aurelien-mondon/, personal website: http://extremism.hypotheses.org/. Aaron Winter, email: a.winter@uel.ac.uk, twitter: @aaronzwinter, university profile: https://www.uel.ac.uk/Staff/w/aaron-winter, personal website: https://aaronzwinter.wordpress.com/, academia.edu: https://uel.academia.edu/AaronWinter.
} 


\section{Introduction}

In the aftermath of the attack on the office of Charlie Hebdo in January 2015, one could see and hear the statement 'Je suis Charlie' appearing throughout Paris, France and the world. The public narrative was unequivocal: this was an attack on freedom of speech - designated as the cornerstone of democracy and freedom itself. Charlie Hebdo's journalists were proclaimed as martyrs in the struggle for free speech, their courage symbolized in the 2006 publication of provocative cartoons of the Prophet Muhammed. They did what 'We' were afraid to do and mourning their loss seemed insufficient: 'We' must identify if not become them in solidarity and resistance. On the 7th of January and for weeks to come, the streets of Paris and the west, Facebook pages and Tweeter feeds were filled with those calling themselves 'Charlie'. Criticising this essentialist and absolutist vision of understanding fell outside of freedom of speech and was considered something akin to cowardice if not treason, as witnessed in the many headlines about children refusing to obey the minute of silence in French suburbs (Berretta 10 January 2015, Leconte 14 January 2015, Beyer and Verduzier 20 January 2015). This communion around the slogan 'Je suis Charlie', and the self-righteous defence of freedom of speech under the protection of the state, its police and army, hid a multitude of inconsistencies and contradictions. The most notable was the photo opportunity with the leaders of the 'free' and not so free world (and the war on terror) leading (or pretending to lead) the march of solidarity, whose record with regard to freedom of speech and the press was heavily criticized as hypocritical (Sherriff 13 January 2015). Yet, despite such discrepancies at the core of the hegemonic discourse, the overall pattern is familiar: widespread and normalized criticism of an essentialized Muslim threat for its hatred of 'our' liberal freedom and tolerant societies, even as 'our' countries pass - and the population at large chooses to ignore - counter-terrorism and extremism legislation that curtails those very freedoms. This has become common place since US President George W. Bush (20 September 2001) stated in his 9/11 address, prior to the establishment of Homeland Security and the Patriot Act, 'They hate our freedoms: our freedom of religion, our freedom of speech, our freedom to vote and assemble and disagree with each other', which became a mantra of the American-led war on terror. Islam has become central to the contradictions inherent to the construction (and presentation) of our identity and self-image as citizens of free and egalitarian liberal democracies: from evocations of free speech in defence of Islamophobes, while monitoring and censoring political speech under the auspices of countering Muslim 'hate' preachers and extremism, to evocations of gender rights in the west, particularly around banning the hijab and burka in the name of emancipation. As such paternalistic narratives developed and disproportionately targeted Muslim communities, they have distracted 
from failures to achieve gender equality on a structural level, as well as failing to acknowledge the growing anti-feminist backlash within western liberal culture.

This article will examine the construction, functions and relationship between the diverse and changing articulations of Islamophobia. The aim of this article is to contribute to debates about the definition of Islamophobia, which have tended to be contextually specific (and sometimes universalized), fixed and/or polarized between racism and religious prejudice, between extreme and mainstream, state and non-state versions, or undifferentiated, and equip those interested in the issue with a more nuanced framework to: (a) clearly delineate articulations of Islamophobia as opposed to precise types and categories; (b) highlight the porosity in the discourse between the more extreme articulations widely condemned in the mainstream, and the more normalized and insidious ones, which the former tend to render more acceptable in comparison; (c) map where these intersect in response to events, historical and political conditions and new ideological forces and imperatives; and (d) compare articulations of Islamophobia in two contexts, France and the United States (US), in order to demonstrate both contextual differences and overlap and the application of our analysis and framework.

The framework developed in this article is built around two main articulations of Islamophobia: an illiberal and a liberal kind. These broad articulations do not work in opposition, as their borders are fuzzy, and that one cannot survive without the other giving it legitimacy. To provide some essential background, the first part of the article provides an overview of definitions of Islamophobia and debates in the field, and explains and justifies our use of the term Islamophobia over alternatives such as anti-Muslim racism. The second and third sections develop the two articulations of Islamophobias we believe are essential to provide a comprehensive picture of the current state of racism towards anyone deemed Muslim.

Throughout the article, examples from France and the United States are provided to illuminate the way in which different articulations of Islamophobia emerge and how it has become increasingly common and in some cases normalized and hegemonic, through the interplay between its liberal and illiberal articulations. These cases provide an excellent opportunity for comparative analysis of elite discourse (media, politicians and academics). Both are secular republics, right-based with a liberal legal and political order and history and significantly both experienced social revolutions in the 1960s and a 'culture war' backlash today, which is key to our analysis as stated earlier. Yet, they are also very different and allow for contrast. France has dominant linguistic-ethnic national identity, historical state religion, a significant and conflicted history through orientalism, colonialism in North Africa and 
post-colonial immigration, whereas the US is a white settler former colony, with a history of slavery and an immigration society, where Muslims have been overshadowed by a history of more developed anti-Black and anti-Mexican, as well as wider anti-Hispanic, racisms. Yet, both have seen a rise in both anti-Muslim rhetoric, attacks and movements on the extremes and more worryingly, in the mainstream, including in democratic electoral politics.

\section{Islamophobias: Definitions and debates}

In 1997, the Runnymede Trust dedicated a report to the rise of Islamophobia in Britain which it defined as 'unfounded hostility towards Islam' (Runnymede Trust 1997, 1). ${ }^{1}$ However, it is since 9/11, that Islam and Muslims, and closely linked, the issue of Islamophobia, have become central to public, policy and research debates and agendas (Morey and Yaqin 2011). In Secularism, Religion and Multicultural Citizenship , Geoffrey Brahm Levey and Tariq Modood (2008) pointedly note:

The Islamist attacks of 9/11, the Danish cartoon affair and rioting by Muslim youths in France [and we would presume Charlie Hebdo would be added now] are just some of the events that have caused the 'Muslim question' to become a key issue of public debate in many western democracies.

Various surveys have shown in recent years that 'anti-Muslim biases' (Taras 2013, 426-431) have been prevalent across much of Europe (for a more thorough overview in France, see (Hajjat and Mohammed 2013, 37-68) and in Britain, see (Field 2007)). While it is too early to have a precise picture, Islamophobic sentiment and attacks appear to have increased throughout the western world following the attacks in Paris in 2015 (Mark 18 November 2015, Al-Othman 1 December 2015, Friedersdorf 16 November 2015, LeMonde.fr 17 July 2015). According to data compiled by TellMama in the UK, in the week following the November 2015 Paris attacks, hate crimes against Muslims increased more than $300 \%$ to 115 and most victims were Muslim girls and women in traditional Islamic dress' (Mogul 23 November 2015). Hate crimes against Muslim and attacks on mosques in the United States also rose in 2015. According to multi-state research by the Center for the Study of Hate and Extremism at California State University, San Bernardino, hate crimes against Muslims rose 78\% from 110 in 2014 to 296 in 2015, and anti-Arab attacks rose 219\% from 21 to 67 (Levin and Grisham 2015, Norton 18 December 2015, Lichtblau 17 September 2016). The Federal Bureau of Investigation (FBI) reported that anti-Muslim hate crimes rose 67\% nationally in 2015 from 154 in 2014 to 257, the highest since 9/11 (Potok 14 November 2016, SPLC 15 February 2017). The Southern Poverty Law Center (SPLC) reported that anti-Muslim hate groups almost tripled in number the following year, from 34 in 2015 to 101 in 2016 (SPLC 15 February 2017). This occurred in the context of the 2015 Paris and San Bernardino attacks, as well as Donald Trump's campaign, during which exploited the attacks, 
deployed anti-Muslim rhetoric and called for Muslims to be banned from entering the country and for the establishment of a national Muslim registry (Pilkington 7 December 2015). The SPLC has argued that this played a role in the rise in anti-Muslim hatred and hate crimes during this period (Potok 14 November 2016, SPLC 15 February 2017).

While there is relative consensus about the growing concern regarding 'Islamophobia' or antiMuslim hate, there is no consensus on the label or definition. The focus of research and debate has included a wide range of issues and originates from various perspectives and agendas. Research has focused on issues such as Islam and Muslim history, Muslim identities, media representations, multiculturalism and social cohesion, migration, citizenship, religion and culture, racialization, secularism, gender, sexuality, nationalism, terrorism, extremism and securitization. It is therefore not surprising that, as Chris Allen (2010) has argued, there is no clear and agreed upon definition. This section is thus devoted to explaining our own definitional standpoint as clearly as possible to provide the basis for the framework developed in the following part.

Halliday (1999) and others have argued that the preferred term should be 'anti-Muslim hate' or 'anti-Muslim racism, as hate and/or racism is more accurate than fear (or phobia) and it is directed against a people, rather than a religion. Nasar Meer and Tariq Modood $(2009,338)$ do not reject the term, but argue that Islamophobia needs to be seen in relation to/as a form of racism. Being Muslim is argued to be a belief system and thus a choice, a status one decides to take on willingly, as opposed to a set of characteristics imposed by birth like 'race'. For Raymond Taras $(2013,422)$, 'Islamophobia can be characterized as a cryptic articulation of the concept of race and racism even if overtly it appears as a form of religious-based prejudice'. For Pnina Werbner $(2013,455)$,

Whatever the case, the effects of securitisation and the attacks on Islamic symbols are racist, in the sense that they license the actions and discourses of individuals and groups who promote more offensive racist imaginaries.

Sixteen years after its first report on the issue, it is thus unsurprising that, in the Runnymede Trust's 2013 report 'The New Muslims' (Alexander et al. 2013), Claire Alexander (2013, 5) observes that 'as the "colour line" was for the early 20th century, "The Muslim Question" has become the defining issue of our times.' The forward to the report, Rob Berkeley $(2013,2)$ points out that since 1997 we have seen a shift in domestic and international policy from a focus on equality and justice to issues of security and cohesion, and from race and ethnicity to religion, largely, focused on Muslims. Although the focus is on religion, the distinction between race and ethnicity and religion is not always clear, particularly when it comes to issues of inequalities, state policies and practise (e.g. securitization) and hate in the media and civil society. Alexander $(2013,6)$ notes that: 
Since this period the race equality and religious equality agendas have become increasingly separate, and academic research in these areas has also become distinct... it is now seemingly possible to talk about religion without race and race without reference to religion. In the first instance, we risk separating out Muslims from a broader struggle for equality, and in the second we run the risk of subsuming or erasing the differences between experiences, priorities, groups and subjectivities for a one-size-fits-all definition of racism.

In addition to this article highlighting diverse articulations of Islamophobia and constructing a more complex, nuanced and inclusive definition of Islamophobia, this argument by Alexander highlights the need for a more complex, nuanced and inclusive definition of racism, where Islamophobia fits in. Alexander $(2013,6)$ further points out that:

... the term 'Muslim' [which underpins both Islamophobia and many conceptualisations of it] is too often a codeword for a series of pathologies. If we think of dominant representations, they appear in three main categories: gender (the hijab/forced marriage/ honour killings triad), gangs and grooming, and terrorists/extremists. None of these are good ... and all provide grist to the mill of the born-again racism without-race popular with both the EDL and the so-called liberal left because, apparently, it's not racist to be anti-Muslim.

Overall, the debate between Islamophobia being about religion or race is not solely about what Islam is, but what one wants to say about it and how they do it. Religion does provide a convenient cover for those wishing to argue that they are attacking a belief and not people, and in a context where racism is allegedly unacceptable, wriggle out of or deflect such charges. Defining and seeing Islamophobia only through the prism of religion not only ignores these issues, processes and effects, but is particularly problematic (or functional) in so-called secular societies such as France, Britain and to a lesser extent in the United States, where criticism of religion is considered a healthy and necessary practice to allow for freedom of thought and expression. This is even the case when the identification and discourse about Islam as a 'religion' slips into 'culture', although the latter brings us closer to a form of racism, which will be returned to. In this context, the Islamophobe is often praised for breaking taboos in the name of freedom of speech and secularism. This is particularly the case regarding Islam as it is often considered to take 'a conservative line' on issues such as gender, sexuality and equality in general, which have come to symbolize liberal causes and liberalism in the post-60s west. As highlighted by David Theo Goldberg (2006, 345), 'Islam is taken in the dominant European imaginary to represent a collection of lacks: of freedom; of a disposition of scientific inquiry; of civility and manners; of love of life; of human worth; of equal respect for women and gay people'. For Sayyid (2010, 1), its detractors perceive Islamophobia as simply a fig leaf behind which 'backward' (sic) social practices and totalitarian political ambitions are covered up and afforded bogus exemption 
from legitimate criticism and challenge'. Therefore, in this article, we do not take the term 'Islamophobia' literally to mean fear (beyond a psychoanalytic reading in which underlying fear is an element), but use it both as the most widely used term and to accommodate different forms of hate that includes those focused on different aspects, including those claiming to be referring to the religion as opposed to people or 'race'.

Key to our framework is the understanding of Islamophobias as articulations rather than selfcontained categories. Our focus is thus on discourse, and is influenced by the post-structuralist theory and the so-called Essex school in particular (Laclau 2005, Laclau and Mouffe 1985). Through the different modes of articulation outlined in the following section, the signifier 'Muslim' and 'Islam' are constructed in different manners, but ultimately, they represent an Other, often described along racist lines in the current hegemonic discourse in much of the west. Yet, we argue, it is only through the dual offer of what we define as illiberal and liberal and Islamophobias in this article that this racist discourse can become naturalized and common sense, since it allows for those espousing the liberal position to justify their racist discourse by opposing it to the illiberal articulation, even though both are part of the same exclusionary paradigm. While it remains conceptual, contingent and may be contested, the distinction we make between the illiberal and liberal articulations is present to accommodate different articulations and acknowledge the construction of an opposition by those espousing the liberal version for functional and strategic reasons: to displace racism and appear more mainstream. We acknowledge that this obscures their shared racist basis and eventual convergence, but argue that the discursive and functional distinction should be examined.

We thus see Islamophobia as a construct, and the Muslim signifier as one which does not come from the individual Muslim in a subjective manner, but is defined by the onlooker in a position of power and imposed onto people through various types of generalization, misperception and stigmatization, such as the so-called secular and anti-terrorist laws, but also through the media coverage of Islam (Liogier 2016, Deltombe 2005, Kundnani 2014). Such constructions can be articulated through different types of discourses, from the more traditional forms of biological racism in unreconstructed far-right and white supremacist circles, to more 'evolved' forms of racism based on culture and even progressive tropes. Political actors across the spectrum rarely limit themselves to one of these articulations, and yet their distinctiveness is key to legitimize, normalize and internalize certain forms of racism as they appear to stand in opposition to more reviled forms. It is precisely these articulations of hate which are central to this article, and how Islamophobia springs from different sources and discourses and serves different purposes, contexts and constituencies, from the illiberal, unacceptable and extreme racist hate to the more liberal, acceptable and mainstream, but 
ultimately intersects. As noted by Mattias Ekman $(2015,1998)$, 'Islamophobia is framed in relation to various national and transnational political actors and processes, and depending on the topic, events or circumstances, it intersects with various political rationales and processes'.

In the following sections, we construct a framework to account for what we consider the two most prominent articulations of current Islamophobic discourse to provide a more flexible and comprehensive way to delineate Islamophobias and thus address them and where they intersect more precisely. These are, as stated, illiberal Islamophobia and liberal Islamophobia.

\section{illiberal Islamophobia: Highlighting and marginalising the extreme and unacceptable face of hate}

This section provides an analysis of what we call illiberal Islamophobia. It is 'illiberal' inasmuch as it is not only not accepted by the liberal norm, but denounced as unacceptable and alien to our post-racial societies (Lentin and Titley 2011), thus allowing the legitimization of other, less obvious and less racialized forms. Our distinction between the liberal and illiberal articulation here is not so much based on political and ideology theory, but rather on the perceived quality of each concept in the mainstream discourse. Liberal thus refers to the prevalent obedience to the constitution and the rule of law particularly regarding equal treatment of citizens, and a loyalty to the deliberation processes central to liberal democracy particularly in the form of elections. Illiberal in our case refers to the treatment of certain groups, particularly based on ethnic and/or cultural generalized traits, and the possibility (discursive or otherwise) to circumvent the rule of law, the constitution and even electoral results should a threat be considered serious enough. While 'extreme' and 'mainstream' Islamophobias could be considered more appropriate, we argue that what we term 'liberal Islamophobia' occurs both on the extreme and in the mainstream. In addition to this, as our examples illustrate, liberalism is a concept around which actors articulate their opposition to Islam and Muslims, whereas 'extreme' and 'mainstream' are not. Not only has Islamophobia experienced a mainstreaming (through the liberal articulation), but so too have what were once deemed 'extreme' or far-right ideologies, groups and movements, often by appealing to liberal Islamophobia as will be examined. The most notable examples being the Front National in France, the white nationalist 'Alt-Right' that has emerged in the United States (SPLC 2016), and United Kingdom Independence Party (UKIP).

Illiberal Islamophobia commonly emerges from exclusivist ideologies, discourses and identities associated with easily recognisable forms of racisms, typically originating on the far-right and within ultra-conservative circles. This type of Islamophobia is closest to traditional racism and often presents Islam as monolithic and innately threatening and inferior (in terms of 'race' if not also culture). It is essentialist and total as it includes all Muslims without making distinctions in terms of 
the specific belief, background ideology, behaviour or activity of individuals or sub-groups. Muslimness becomes an immutable characteristic (akin to biology): Muslims are innately Muslims and there is no loyalty test possible. It often targets those belonging to visible racial or ethnic groups associated with Islam, most notably Asians and North Africans, regardless of their faith or religious identification. This is most obvious in attacks on Sikhs. Illiberal Islamophobia can be witnessed in attacks, whether discursive or physical, against Muslims and mosques, but also in calls for repatriation or even genocide. However, illiberal Islamophobia is not synonymous to traditional, biological forms of racism, and is not restricted to white supremacist circles. While it is indeed most clearly related to traditional right-wing race hate, its most pervasive and insidious occurrences are represented by what Etienne Balibar, amongst others (Taguieff 1994, Barker 1982), has termed the 'new racism':

a racism which has as its dominant theme not the biological heredity, but the irreducibility of cultural differences; a racism which, at first sight, does not imply the superiority of certain groups or peoples over others, but 'only' the noxiousness of the removal of borders, the incompatibility of ways of life and traditions (Balibar 1997, 33).

This type of discourse remains very much on the margin of politics because of its illiberal quality, insofar as it advocates for different rights to different people and cultures, but it occupies a space between the most reviled forms of racism based on biology and its more insidious occurrences based on culture. This is enabled by several factors specific to Islam and Muslims, most notably the status of Islam as a religion, returning to the previous discussion, as well as the legacy of colonial discourses in France and Britain, migration, and essentialized constructions of cultural difference. In terms of the latter, this can take the form of colonial cultural essentialism and hierarchies or a pseudo progressive anthropological one. This opens the door to liberal Islamophobia by concealing its racism behind 'culture'.

Obviously, as with other ideological elements, the borders between what is acceptable or not, what is mainstream or extreme, are fuzzy and in constant evolution, which has been both useful and damaging for those parties and movements trying to walk the tightrope. In France for example, illiberal Islamophobia is mostly associated with the far-right, and the Front National (FN) in particular. The party, founded by neo-fascists in the early 1970s, took a conscious turn in the 1980s as its radical and uncompromising strategy based on racist and proto-fascist politics was clearly failing (Mondon 2013). With the arrival of a new generation of thinkers and expert politicians, the FN turned gradually to a strategy of normalization, which meant moving away from crude racist politics towards a 'new' racism based on culture. Under the impulse of the Nouvelle droite and Alain de Benoist's theories in particular (Taguieff 1994, Bar-On 2013), the FN implemented a form of right-wing Gramscism: cultural 
power must come before political power. Far-right measures and ideological tenets became hidden under a veneer of softer rhetoric; the concepts of invasion, conspiracy and violence remained omnipresent throughout the programme, but were camouflaged by apparently positive or at least non-threatening labels.

This discursive shift has accelerated under the leadership of Marine Le Pen, by moving away from its traditional racist past and discourse to a more hegemonic strategy aimed at securing the common understanding of key concepts such as the Republic and laïcité (secularism) (Alduy and Wahnich 2015, Crépon, Dézé, and Mayer 2015). However, the FN's strategy has required an ideological stretch from the party as its quest to reach a broader electorate cannot take place at the expense of the more traditional and active section of supporters (Mondon 2014). Therefore, despite its attempts at reshaping its discourse in a more liberal progressive form, the FN remains the symbol of illiberal Islamophobia, although not its crudest proponent. As such, it falls outside the remits of what is considered acceptable in the hegemonic discourse and apart from the most ideologicallyfocussed groups on the right, most have tried to distance themselves from such labels.

In the United States, illiberal racisms have not been limited to the far-right. The US provides an interesting supplement to the story in France as a fellow republic with a tension and contradiction between its liberal and egalitarian premise and reactionary, illiberal practices and state formations from settler colonialism and slavery to Jim Crow segregation, supported by movements such as the Ku Klux Klan (KKK). Yet, as Muslims experienced increased suspicion, securitization and attacks following 9/11, the American far-right did not target them. Instead, what we saw was not the Islamophobia and anti-Muslim hate, one would expect, but statements of support for al Qaeda (SPLC 2001, Winter 2010). ${ }^{2}$ One of the arguments as to why the far-right were supportive of the attacks and al-Qaeda was their shared anti-Semitism and illiberalism and opposition to democracy and the American government (Michael 2006, Winter 2014). August Kreis of Aryan Nations posted the piece 'Why Islam Is Our Ally' following 9/11 and later established the position of 'Minister of Islamic Liaison' (Winter 2014).

Although not technically on the far-right, the religious right, another bastion of illiberalism that was on the ascent during the Bush era (Martin 2005) and was associated in this area with the inflammatory Koran burning tactics of Pastor Terry Jones, was not initially focused on Islam. Immediately following 9/11, Jerry Falwell, the founder of the Moral Majority, issued a statement that blamed liberals, feminists, 'gays' and 'lesbians', but not Muslims. ${ }^{3}$ 
A more coherent ideological Islamophobic project was gestating in the early 2000 s from within the neo-conservative movement, who shifted their focus from the traditional 'Arabs' to 'Muslims', but it was primarily focused on the Middle East and foreign policy, specifically the 'war on terror', the invasion of Iraq and US support for Israel. Notable names included commentators Thomas Friedman and Daniel Pipes, who ran Middle East Watch and Campus Watch. There was also the Clarion Project, Jihad Watch, Act! for America, Center for Security Policy (CSP) (Kazem 20 June 2016). While neo-conservatives parted ways with the religious and far-right on social issues such as gender rights and abortion, they were illiberal on academic freedom of speech when it came to American foreign policy and Israel. Examples include Pipes' Campus Watch, the David Horowitz Freedom Center and Students for Academic Freedom, opposing 'leftist indoctrination' in academia. Horowitz saw liberals, the left and political correctness as totalitarian, and thus sharing something with Islam, in writing such as Unholy Alliance: Radical Islam and the American Left (Horowitz 2004).

Islamophobia did not emerge as a salient domestic political issue until 2009-10 with three mainstream developments. The first was the so-called 'Birther' movement which sought to prove that President Obama was a Muslim born in Kenya and was supported by Pamela Geller and Robert Spencer's Stop Islamization of America (SIA), inspired by its European counterpart, and Donald Trump. The second was the Republican Congressman and Chairman of the House Homeland Security Committee Peter King's hearings on 'The Radicalization of American Muslims and response of the community', and SIA's 'Ground Zero Mosque' campaign, but these came and went without wider national mobilization. There are several possible reasons for this late start, lack of focus for the right and lack of popular national traction: (1) attention has historically been focused on African-Americans and Hispanic immigrants; (2) Muslims have historically been identified as 'good immigrants', with the largest Muslim population in the United States living in Dearborn Michigan and working in the car industry or coming from anti-American regimes and taking refuge in the US; (3) If Muslims are seen as religious and culturally and socially conservative on gender and sexuality, they would not present a challenge to the right, even if seen to reject freedom of speech; and (4) Anti-Muslim movements were fragmented, appealing to often contradictory interests and ideologies.

Movements such as PEGIDA in Germany, the English Defence League (EDL) in Britain or Riposte laïque in France have tried to use the lack of clarity between the different articulations of Islamophobia to distance themselves from traditional racist politics. As Kundnani (2014, 238-239) noted, the EDL's first video plundered 'antifascist imagery in an attempt to construct a popular front against Islamic extremism ... By claiming to attack Muslim extremism rather than Muslims per se, the EDL hoped to dispel the suspicion that it was just another fringe, racist, far-right group'. It did so by 
highlighting gender and setting up an LGBT division. While such attempts were thwarted by the obvious racist leanings of most of its propaganda, they demonstrated the increasingly blurry borders between the crudest form of Islamophobia and more accepted and even mainstream forms.

Therefore, the illiberal articulation of Islamophobia has two elements central to our argument. The first is that it can be defined as a discourse falling outside of the liberal norm because of its calls for discriminatory practices based on culture, ethnicity and or/religion, but at the same time stirring clear from the most common definition of racism. The second element relates to the positioning of the contingent line drawn between the mainstream and the extreme, what is acceptable and what is unacceptable. It is the construction and containment of a clearly delineated type of Islamophobia at the margins of the political spectrum, one which falls outside of the liberal, mainstream ideal based on a liberal democratic fantasy because of its essentialism, unmediated call for violence, total rejection and open discrimination, which make it possible for subtler forms of Islamophobia to enter the mainstream discourse due their apparent allegiance to liberal democratic rules.

\section{From the illiberal to the liberal, slippage and distinction within Islamophobic discourse}

While the most caricatural forms of illiberal Islamophobia are usually easily recognized and widely denounced in mainstream discourse, we argue that a more mainstream trend has taken hold of public discourse and become increasingly normalized. The liberal articulation of Islamophobia can be contrasted with the illiberal one by its proclaimed allegiance to fantasized liberal and democratic principles, but both share a basic structure. In both cases, hate and prejudice against Muslims focuses on culture, as in the case of colonial Orientalism, which current forms have inherited and can draw on (Said 2003, Meer 2014). The difference is that the illiberal form, finding its roots in traditionally racist movements, draws on the anti-Arab racism of earlier colonial and cold war discourses, and the liberal form takes its cultural understanding of racism a step further by explicitly distancing itself from, and even repudiating openly traditional racism and hate, by appearing to focus only on 'religion', 'culture' and/or values, and/in relation to rights and tolerance as values inherent to Western societies

Therefore, contrary to illiberal and more extreme forms of Islamophobia, liberal Islamophobia is anchored in a pseudo-progressive narrative in the defence of the rule of law based on liberal equality, freedom and rights (e.g. liberal versions of freedom of speech, gender and sexual equality). Critiques of Islam and Muslims based on illiberalism, particularly in terms of free speech, found their contemporary roots in the wake of the fatwa issued against Salman Rushdie for The Satanic Verses (Rushdie 2008, Appignanesi and Maitland 1989). This period also saw the emergence of Women Against Fundamentalism, founded in 1989 to challenge what was seen as the growth of religious 
fundamentalism and was both feminist and anti-racist. The issue of gender became increasingly prominent following 9/11 with the invasion of Afghanistan justified party by coalition partners in terms of emancipating women from the Taliban (Khiabany and Williamson 2011, 175). In more recent years, there has been increased attention on the gendered aspect of Islamophobia in response to calls to ban, and actual bans on, different Muslim head coverings. Corresponding to these developments and other gender-related ones, there has been a growth in literature on gender and Islamophobia, notable examples include Irene Zempi and Neil Chakraborti's Islamophobia, Victimisation and the Veil (2014), Christine Delphy's Separate and Dominate: Feminism and Racism after the War on Terror (2015), Narzanin Massoumi's Muslim Women, Social Movements and the 'War on Terror' (2015) and Naaz Rashid's Veiled threats: Representing the Muslim woman in public policy discourses (2016). In terms of sexuality, an early case was witnessed in the Netherlands with Pim Fortuyn and his use of country's liberal sex laws and gay rights as a platform to campaign against Islam. More recently, the reaction to the 2015 Charlie Hebdo attacks rekindled this type of discourse and blurred the boundaries further.

Before going any further, it is important to note that, by stating that mainstream articulations of Islamophobia are couched in the defence of gender or sexual rights, means that any criticism directed at discriminatory practices is necessarily Islamophobic. While oppression can certainly be expressed through particular versions and implementations of Islam, what this article describes as mainstream Islamophobia is the creation of a loosely defined Muslim culture and community inherently and homogenously opposed to some of the core values espoused in a mythical essentialized culturally homogenous, superior and enlightened West. In this vision, the progress achieved by the West is taken uncritically and portrayed as a natural state of things ignoring that democracy, human rights, free speech, gender and sexual equality and rights remain precarious, unequally distributed and unfulfilled.

A similar concept to that which is studied here, has been discussed by Deepa Kumar in Islamophobia and the Politics of Empire. In it, Kumar differentiates the liberal form not from an illiberal one, but 'conservative Islamophobia'. She argues that the key characteristics of the liberal version are: 1. The rejection of the 'Clash of Civilizations' thesis; 2. The recognition of 'good' Muslims; and 3. A willingness to work with 'moderate Islamists' (Kumar 2012, 133). She also adds that the liberal version is 'rhetorically gentler', but that it remains racist and imperialist as it 'takes for granted the "white man's burden" (Kumar 2012, 133). This last aspect is crucial, as Kumar links the emergence of liberal Islamophobia to that of liberal imperialism, and both to the Obama era. 
While Kumar's contribution is extremely valuable, we argue here that even though mainstream/liberal Islamophobes may reject the absolute essentialist reading of the 'Clash of Civilizations', they do articulate nonetheless a civilizational/cultural clash when describing the differences between Islam and the 'West' in terms of free speech, gender and sexuality. Furthermore, the neo-conservatives central to the definition of 'conservative Islamophobia' did make an effort to distinguish between 'good' or 'moderate' Islam or Muslims and extremists, as well as emphasising liberal issues, or liberal approaches to issues such free speech, human rights, gender rights, in imperialist terms when advocating wars. First lady Laura Bush's intervention on the situation for women and girls in Afghanistan in the lead up to the invasion is a perfect example of this (Gerstenzang and Getter 18 November 2001).

In our framework, and to take the argument beyond the US context, two aspects make the liberal articulation of Islamophobia distinct, not from conservative, but extreme and illiberal forms:

- It allows for limited distinctions between 'good' (redeemable) and 'bad' Muslims subject to a loyalty test, that is through (demands for) explicit expressions of opposition and apologies from 'moderate' Muslims, even though the line to satisfy such demands is arbitrary, and always moving out of reach.

- It emphasises the apparent inclusion of other ethnic and religious groups typically hated by the far-right and traditional racists. Such groups provide a veneer of tolerance and progressivism as their victimization is acknowledged, albeit diverted onto a particular scapegoat: the racialized and stigmatized group can join if 'They' decide to integrate through hate.

We argue that while this may be a characteristic of mainstream and thus liberal Islamophobia and serves to provide cover against accusations of racism, it is used by conservatives and even those usually associated with the more illiberal articulation as well, as demonstrated further.

As a result, a simplistic and unitary picture emerges in opposition to Islam whereby the West stands unified behind a fantasized version of equality and freedom based on a clear negative homogenizing generalization or stereotype about Islam and Muslims, and positive one about the 'West'. Strengthening the opposition between 'Us' and 'Them', this picture wilfully ignores the tensions within liberalism in terms of the legacy(ies) of the Enlightenment, universalism, racism, colonialism, imperialism and patriarchy, as well as the inequalities and curtailment of freedoms within the 'West'. Contrary to illiberal forms of Islamophobia taking their ideological impulse from antiegalitarian and authoritarian movements, liberal islamophobia acts as a decoy to provide 'Us' with a 
righteous sense of ourselves as the defenders of a more progressive vision of the world, and displaces these tensions, failures and inadequacies onto Islam as a sole responsible for our problems.

To gain legitimacy, it is thus crucial that liberal Islamophobia goes beyond its attacks on Muslims, and appears to challenge traditional far-right and ultra-conservative discourses and ideologies. In its self-proclaimed yet limited opposition to the reviled 'racists', 'sexists' and 'fundamentalists' of all kinds, it enables far greater mainstream and even progressive acceptance. As has already been mentioned, freedom of speech, gender rights and secularism have been key elements to justify the mainstreaming of Islamophobia. To illustrate this trend, key themes were selected from our case studies.

\section{Liberal Islamophobia and free speech}

The reaction to the tragic events in Paris in January 2015 demonstrated further the prevalence of the liberal articulation of Islamophobia in France. While most commentators, be they journalists, politicians or academics, warned against laying indiscriminate blame against Islam, their initial disclaimers were often lost in simplistic and stigmatising analysis opposing free speech and anyone loosely linked to Islam. In the prevalent discourse, the 'Muslim community' was commonly described as foreign to 'our' land, values and beliefs. To cite but one example, Alain Juppé (7 January 2015), former French Prime Minister, Mayor of Bordeaux and progressive runner-up in Républicains' primaries, while warning against divisions, told French Muslims on the radio after the attacks that it is their responsibility 'to speak up', as he believed that 'there can be a responsible, enlightened Islam [islam des lumières]'. This had been an ongoing trend which originated in what Hajjat and Mohammed (Hajjat and Mohammed 2013, 12-16) have called an 'islamophobie de plume' (public intellectual islamophobia). This new hegemonic status was made clear in late 2014 and early 2015 when the two best sellers in France and across Europe, Michel Houellebecq's Submission (2015) and Eric Zemmour's The French Suicide (2014), played on the apocalyptic fear of a conquering Islam. Both were advertised widely as breaking further taboos, even though their authors were very much part of the 'establishment' with a broad access to much of the mainstream media in the country, and with their books published by mainstream publishers. Mixing liberal and illiberal Islamophobic articulations, both implied with more or less subtlety that Islam did not hold sole responsibility for France's demise, and that a culture of emancipation was in fact to blame. For Zemmour in particular, the demise of France in the hands of Islam has taken place as a result of the feminization and homosexualization of the country's population and politics, thus allowing a testosterone-fuelled and macho Muslim youth to take over. While Zemmour's Islamophobia has been widely denounced in the mainstream media, but also used as publicity by his publisher, his ubiquitous presence on TV, the radio and the press has 
allowed for a more nuanced Islamophobia, anchored in liberal values such as secularism to become naturalized. It was therefore not surprising that the day before the first anniversary of the Charlie Hebdo events, Elisabeth Badinter (6 January 2016), a prominent mainstream public intellectual declared on France Inter radio: 'one should not be scared to be called an Islamophobe'.

In the US, freedom of speech being constitutionally protected in the first amendment and part of the political identity and mythology of American nationalism and exceptionalism, it is thus unsurprising that this would be central to Islamophobia, particularly in light of attacks on journalists and cartoonists. Yet, this was not something that the right could easily champion as it was aligned with the religious right who were authoritarian and opposed to anti-religious speech (e.g. blasphemy). With the right so fragmented and contradictory on Islam and Muslims, Islamophobia did take root in liberal quarters. Most notably, though Bill Maher, host of Real Time, and fellow new atheist Sam Harris, Chief Executive of Project Reason and author of Islam and the Future of Tolerance: A Dialogue (Harris and Nawaz 2015), who have been described as proponents of the 'new liberal Islamophobia' in the media (Kolhatkar 10 October 2014). In the polarized political landscape of the United States, the association of anti-Muslim sentiment with the right would make it untouchable by liberals and thus difficult to spread, but Maher's focus on issues of free speech, women's and LGBT rights allowed for such mainstreaming.

Even before the attack on the offices of Charlie Hebdo, Maher stated on his show 'Islam is the only religion that acts like the mafia that will fucking kill you if you say the wrong thing'. He continued:

... If vast numbers of Muslims across the world believe - and they do - that humans deserve to die for merely holding a different idea or drawing a cartoon or writing a book or eloping with the wrong person, not only does the Muslim world have something in common with Isis. It has too much in common with Isis (Jalabi 7 October 2014).

Maher defended himself against accusations of Islamophobia by arguing, based on the assumption that liberals are by definition, against racism and prejudice '[w]e are not bigoted people. On the contrary! We're trying to stand up for the principles of liberalism!' (Jalabi 7 October 2014). He even chastised liberals for not doing the same:

To count yourself as a liberal, you have to stand up for liberal principles: Free speech. Separation of church and state. Freedom to practice any religion or no religion without the threat of violence. Respect for minorities, including homosexuals. Equality for women (Maher 27 September 2014).

This critique of liberals served to shame liberals and soften conservatives to the point where the space was created to allow for a broader based and more widespread acceptance of Islamophobia. The 
Charlie Hebdo attack was used to justify that Maher had been correct. While the US State Department attempted to defend free speech, while not exacerbating tensions and fuelling Islamophobia ${ }^{4}$, the Charlie Hebdo attack gave Islamophobes on the right, such as SIA, an opportunity to recapture momentum lost since the 'Ground Zero Mosque' Protests. It was a 'Prophet Muhammad Art Exhibit and Cartoon Contest' in Texas, co-organized with Jihad Watch, that would be framed as a tribute to Charlie Hebdo and a challenge to Muslims. According to Geller: 'We decided to have a cartoon contest to show we would not kowtow to violent intimidation and allow the freedom of speech to be overwhelmed by thugs and bullies'. During the event, two gunmen committed a drive-by shooting, hitting a security guard, which Geller called a 'war on free speech' (Bever 4 May 2015). ${ }^{5}$

\section{Liberal Islamophobia and gender rights}

The use of gender rights has been particularly prevalent in the stigmatization of Islam. Some features and manifestations of what we identify as elements of mainstream Islamophobia relate to what has been defined as 'homonationalism' (Puar 2007) and 'femonationalism' (Farris 2012). Building on the work of Jasbir Puar, Sara Farris uses the term 'femonationalism' 'to address the political economy of the discursive formation that brings together the heterogeneous anti-Muslim and antiimmigrant concerns of nationalist parties, some feminists, and some governments under the idea of gender equality'. Just has homosexuality and gay rights became entwined with American (and western) nationalism for Puar, and Israeli in the form of 'pinkwashing', feminism and women's rights have become considered parts of 'our' national tradition. Yet this nationalistic appropriation of apparently progressive, albeit fantasized struggles for minority rights has allowed many to attack Islam on the basis of its supposed inherent illiberalism and inherent incompatibility with 'our' way of life.

Defences of women's rights that emerge from within the mainstream Islamophobic discourse are typically imperialist, paternalistic, racist and even sexist reassertions of the patriarchal order: calls to ban the hijab, burka or burkini (Mondon 1 September 2016, Mondon and Winter 28 July 2016), as has been the case in France, present themselves as attempts to emancipate women from an oppressive patriarchal culture, but really only target and punish women with charges and penalties by demonising a particular garment, without ever considering the agency of the bearer. Muslim women are thus given a choice: remove the items or remove yourself from the public sphere and associated rights and resources (e.g. employment, social services and education) and return to the private sphere. Whether this flawed argument is based on secularism, free speech or gender rights, mainstream islamophobia demands from anyone wishing to belong to its fantasized version of the enlightened west to make a choice between the defence of these values and that of a particular minority. As Christine Delphy pointedly demonstrated in the French debate on the hijab, many French feminists 
felt forced into making a false choice between racism and sexism (Delphy 2006, see also Scott 2007). The basis for the exclusion of the other in the name of progress is to be found in new articulations of racism.

This has allowed movements traditionally thought of as extreme to move closer to the centre ground. Recently, Pegida and other groups have attempted to exploit the New Year's Eve 2016 sexual assaults in Cologne which were blamed on Muslim refugees. In response, feminists have been criticized for not rejecting the use of feminism and women's issues in anti-Muslim politics specifically, and called on to do so (Ingulfsen 18 February 2016). It is worth noting that while some individuals and groups spoke out about the sexual assaults, including in ways that did not challenge anti-Muslim politics, the use of feminism in such politics has not been widely endorsed by feminists, and is far from feminism. The use of such discourses by Pegida and others are examples of the traditional racistnationalist patriarchal attempt by men to appoint themselves protectors of white women from men from different cultures and races seen to pose a sexual threat.

In the US context, Maher has claimed to champion women's rights when it comes to Islam, and played host to reformist and ex-Muslim women. To quote:

91\% of Egyptian women have had their clitorises forcibly removed. 98\% of Somalian women have. Ayaan Hirsi Ali [...] is one of them. She was scheduled to speak at Yale last week, but the school's atheist organization - my people - complained that she 'did not represent the totality of the exMuslim experience.' Meaning what? The women who like mutilation? You're atheists! You should be attacking religion, not siding with the people who hold women down and violate them, which, apparently, you will defend in the name of 'multiculturalism' and then lose your shit when someone refers to Chaz Bono by the wrong pronoun (Maher 27 September 2014).

Yet, Maher has not been exactly liberal on gender issues, and associates such tolerance with femininity: 'For a lack of a better term I would say the feminine values are now the values of America, sensitivity is more important than truth, feelings are more important that facts' (Maher 2016). As the feminization thesis indicates, he employs gender stereotypes as a matter of course and provocation. In one case, he combined an attack on Muslims and sexism: 'Dealing with Hamas is like dealing with a crazy woman who's trying to kill you - you can only hold her wrists so long before you have to slap her' (Maher 2016).

While most conservatives have opposed women's rights broadly speaking, most notably the religious rights, gender was taken up by the neo-conservative SIA who, unlike Horowitz and others, were not committed to opposing campus liberalism. SIA co-founder Robert Spencer wrote 'The Violent 
Oppression of Women in Islam' and 'Islam: Religion of Bigots', and ran Jihad Watch, which 'seeks to bring public attention to: The plight of women under Sharia provisions ...' (Jihad Watch 2016). Horowitz's opposition to Islam and campus liberalism is something shared with former Breitbart editor, icon of the 'Alt-Right' and Trump supporter Milos Yiannopoulos who combines appeals to both liberalism, particularly free speech, and illiberalism in selective ideological ways and has made both Islam and Feminism targets of his attacks. According to Heidi Beirich of the SPLC, 'Milo is the person who propelled the alt-right movement into the mainstream' (Stein 15 January 2015). In his talk on 'Feminism and Islam, the Unholy Alliance' at Western Carolina University on 12 October 2016, Yiannopoulos argued that 'Feminism and Islam are the twin problems facing America today' (Yiannopoulos 12 October 2016), and that the two are in an alliance due to a shared opposition to free speech and penchant for censorship, opposition to the exposure of women's bodies and a desire to control women, as well as hatred of the West. Referring to London Mayor Sadiq Khan's ban on Protein World posters with an image of a woman in a bikini and the words 'are you beach body ready' from the transport system (as an example and like references to so-called 'no-go areas' in France, a warning to America), Yiannopoulos highlighted the fact that Khan is Muslim and asked 'Was this move really to combat body shaming, like feminists wanted? Or was it to make the underground more shariahcompliant?' (Yiannopoulos 12 October 2016). He also argued that feminism's acceptance of political correctness and focus on campus rape culture, western culture and white men, ignores and enables Muslim sexism and violence against women. In that sense, Yiannopoulos is arguing that not only is Islam a threat to women's rights and safety, but so too is feminism (Yiannopoulos 12 October 2016). It is also worth mentioning that Yiannopoulos has also attacked Islam and Muslims for homophobia, highlighting the fact that as a gay man he would be a target, but he criticized the gay community and liberals in general for failing to call out Muslims in the wake of the attack on The Pulse nightclub in Orlando by Omar Mateen on 12 June 12 2016, and focusing instead on gun control (Yiannopoulos 15 June 2016),

Gay people need an end to gun free zones. Gay people need and end to the pointless pacifism of the left because we have a threat on our shores, in our communities, in our societies, in streets not far from here, that requires a response from the minorities the left has given up on. It refuses to protect us, instead it pits us against each other. It creates a victimhood hierarchy with Muslims at the top, well the problem with putting Muslims at the top is they want to kill everyone else on the list.

Returning to the issue of gender, Despite the focus on women's rights, however defined and constructed, it emerged that a US Airforce Research Laboratory report 'Countering Violent Extremism: Scientific Methods and Strategies' claimed that the hijab, far from being oppressive, was a form of 
'passive terrorism' (Buncombe 24 February 2016); Muslim women were no longer victims to be saved, but weapons.

\section{Liberal Islamophobia and secularism}

The religious argument and its place in secular western societies has been key to the mainstreaming of the liberal articulation of Islamophobia. In France, Laïcité (often loosely translated as secularism), a traditionally progressive concept in French historiography and politics, has been brought back into the public debate under purposefully fuzzy and multiple meanings, and thus allowed various criticisms of Islam formulated in pseudo-progressive jargon to enter the mainstream (Mondon 2015). While its original aims, as stated in the 1st article of the 1905 Law on the separation of Church and State, demand that the Republic ensure 'freedom of conscience [and] guarantee freedom of worship limited only by the following rules in the interest of public order', a new understanding aimed directly at the singularising and stigmatising of Islam began to take precedence in the 2000s. The 2004 and 2011 laws banning the hijab and burqa under more general pretence were clear examples of the use of secularism to target Muslim communities (Scott 2007, Tevanian 2005). While the laws were couched in innocuous terms, part of the liberal jargon and apparently respectful of the constitution and rule of law, it was clear that it was the hijab and the burqa, and Islam generally, which were targeted (Delphy 2006). With the focus on laïcité and the law of 2004 imposing a very clear stigma on certain practices said to emanate from an essentialized community, Arabness was replaced by Muslimness, and thus the traditional racist characteristic became much less visible.

Despite being recognized as a religious nation amongst Western democracies with examples ranging from the its founding myths of manifest destiny and religious persecution, its 'one nation under God' motto, freedom of religion in the constitution, high levels of religious belief and religiosity expected of political candidates, the United States is a secular republic like France. Although it does not have an equivalent to Laïcité, the US has a constitutional separation of church and state and no state religion. While this has prevented the institutionalization of religion in politics, it has allowed for the proliferation not just of religions, but activist and politicized ones. The dominant model being the religious right which, instead of promoting religious freedom, has taken a self-interested authoritarian approach to curtailing the influence of secularism and liberalism in education, sexuality and reproductive rights. As such, Islam is not opposed on liberal grounds by the religious right, which has veered from blaming liberals for 9/11 to burning the Koran as a threat to the Christian nation. Where secularism is central to Islamophobia is amongst liberal new atheists such as Maher, as well as Richard Dawkins, Christopher Hitchens and Sam Harris who all appeared on Maher's show. In addition to being involved in the enlightenment referencing Project Reason, Harris is also author of End of Faith: 
Religion, Terror and the Future of Reason (Harris 2004) and bestselling Letter to a Christian Nation (Harris 2008). Harris and Maher targeted the religious right for their beliefs, intolerance and authoritarianism as well. But they did so mostly during the Bush era when they were on the ascent and without acknowledging the difference in power between the religious right and Muslims in domestic and international politics and American society.

Therefore, what we witness with the liberal articulation of Islamophobia is a double standard which betrays its racist basis. In the examples we provided from our case studies, the 'Muslim' becomes the ultimate threat to universalism. However, Muslims are not posited as the only threat as others' demands for equality and emancipation are also constructed as putting the current hegemony at risk. More than simply the racist construction of the Muslim, it is anything different from a very particular, limited and reactionary understanding of the liberal west which is placed under a state of suspicion and potential exclusion. As David Tyrer $(2010,102)$ points out, 'Islamophobia codes the Muslim other in terms of degrees of difference from the universal white male, rather than through the hard logic of pure alterity'.

\section{Conclusion: Fuzzy borders and the mainstreaming of Islamophobia}

The first part of the article discussed briefly some of the many debates currently taking place in academia with regard to Islamophobia and anti-Muslim hate, demonstrating the very flexibility which has made it such a powerful tool. While there are many ways to demonstrate the potency of Islamophobia in our society, this article argues that the division between liberal and illiberal types can help us shed more light as to the ways in which it travels and has been mainstreamed in different political and cultural contexts However, this division does not mean that the concepts are exclusive. In fact, they are linked by the target and at the borders.

As was argued in the article, the acceptance of liberal Islamophobia within the mainstream rests on that of illiberal Islamophobia being both easily identified, contrasted and denounced. Yet the mask slips easily and often, not only because there is a blurred or slippery relationship between the two concepts based on a shared antagonism, target and structure, but also because both are responses or backlashes to the impact of the liberal social movements of the 1960s-80s: feminism, anti-colonialism, LGBT rights and anti-racism despite liberals claiming to champion some of these. Illiberal Islamophobia stands strongly against these and wants the clock turned back. While there was once a clear support in the mainstream elite discourse for these social movements, a counterhegemonic discourse has gained ground since the 1990s positing that the emancipation and equality of some beneficiaries of liberal rights and equality may pose a risk to western culture based around 
universal liberal secular rights, by demanding 'real' equality, and protection from hate speech and against discrimination. Liberal Islamophobia, with its discourse based in fantasized liberal rights and thus appearing progressive, borrows much from what has been called 'new' racism, basing its criticism of Islam on no less a cultural essentialism, it emerges from within a backlash and views particularist movements for rights and equality as part of the cause, and legitimizes and mainstreams all, even illiberal, forms of Islamophobia.

To illustrate this development, this article focused on two cases. The French case demonstrated the increasingly blurry relationship between illiberal and liberal Islamophobias as much of the discourse of the far-right, and the FN in particular, has been mainstreamed by politicians, the media and some prominent public intellectuals and commentators. Beyond the simple yet powerful mainstreaming of far-right exclusivist discourse, Islamophobia has also been legalized and thus further normalized through the laws against the hijab (2004) and the burqa (2011) and the recent debates around the state of emergency in the wake of the 2015 attacks. While Islamophobic extra-judicial violence remains virulently denounced as unrepublican, and thus illiberal, state-sponsored and systemic violence have become the norm in France. In the United States, Islamophobia did not enter the mainstream from the illiberal margins, but was introduced by the security-based neo-conservative version and popularized by liberal commentators such as Bill Maher and Sam Harris, both of which far overshadowed illiberal forms of Islamophobia. The liberal version found its argument legitimized in the wake of the Charlie Hebdo attacks. It was following the November 2015 Paris attacks that the conversation turned from liberalism, freedom and rights back to security and explicit fear and hate, calls for bans on Muslims and Syrian refugees and a spike in hate crimes against Muslims. When sexual assaults in Cologne on New Year's Eve were blamed on refugees and the target were non-Muslim women as opposed to Muslims, the racist illiberal hate overshadows the liberal. This also could be seen in the United States with Trump's campaign threat to ban Muslims from entering the country, a rise in anti-Muslim hate crimes and hate groups in 2015 and 2016 (Levin and Grisham 2015; Norton 18 December 2015, Lichtblau 17 September 2016, Potok 14 November 2016, SPLC 15 February 2017), his candidacy being supported or endorsed by figures in the 'Alt-Right' (SPLC 2016) and wider far-right, former Klansman David Duke and Marine and Jean-Marie Le Pen, bringing the two case studies and illiberal Islamophobias together (Neiwert and Posner 21 September 2016, Hafner 25 February 2016). In response to the rise in illiberalism during the campaign, Salon's Jeffrey Tayler (13 December 2015) called for people to: 'Follow Bill Maher's lead, not Donald Trump's: There's a way to critique ideology behind religion without resorting to hate'. Tayler failed to recognize that Maher set the stage for acceptance of Trump's Islamophobia in mainstream, and that these two articulations were converging. The situation seemed to get worse when Trump was elected, with the SPLC reporting a 
spike in hate crimes against Muslims and other groups in the month following the election (SPLC 15 November 2016), and then when he took office. A week after being inaugurated on 20 January, Trump issued his executive order Protection of the Nation from Foreign Terrorist Entry into the United States. The order banned Muslims from seven countries, including refugees from Syria, from entering the United States for 90 days and suspending the Refugee Admissions Program for 120 days (Merica 30 January 2017). In response, Harris appeared on Real Time on 3 February and both he and Maher opposed it, in the latter's words 'because we are liberals'. Harris argued that a blanket ban was counter-productive because 'we' are 'desperate for moderate Muslims in society' as 'only secular, liberal and former Muslims, frankly, can police this for us' (Harris 2017). Harris, like Tayler, was trying to differentiate between two articulations of Islamophobia and failed to see the Islamophobic construction of the good vs bad Muslim underpinning his argument or the fact that, along with Maher, he had a role in mainstreaming the Islamophobia that Trump mobilized. Although Harris may have a sense that the two articulations are converging, which may lie behind his attempt to police the boundary between them so explicitly at this point in time. This convergence became clear the when Maher hosted Yiannopoulos on Real Time on 17 February and the two bonded, despite different opinions on Trump, over their shared Islamophobia. In the interview, Yiannopoulos complimented Maher by saying 'You're sound on Islam unlike most people on your show' and Maher responded 'Yes, that's true' (Obeidallah 20 February 2017). The French and American cases, for all their differences, testify to the fact that the boundary between illiberal and liberal islamophobia, like that between racism and religious hate, is not only blurry, slippery and porous, but opportunistic, with the common denominator being anti-Muslim hate.

\section{References}

Al-Othman, Hannah. 1 December 2015. "Anti-Muslim hate crimes in London more than triple in the wake of Paris attacks." Evening Standard. http://www.standard.co.uk/news/crime/ antimuslim-hate-crimes-in-london-more-than-triple-in-the-wake-of-paris-attacksa3126646.html

Alduy, Cécile, and Stéphane Wahnich. 2015. Marine Le Pen prise aux mots : Décryptage du nouveau discours frontiste. Paris: Seuil.

Alexander, Claire, Victoria Redclift, and Ajmal Hussain. 2013. The New Muslims. London: Runnymede Trust.

Alexander, Claire. 2013. "The Muslim Question(s): Reflections from a Race and Ethnic Studies perspective." In The New Muslims, edited by C. Alexander, V. Redclift and A. Hussain. 5-7. London: Runnymede Trust.

Allen, Chris. 2010. "Islamophobia: From K.I.S.S. to R.I.P." In Thinking Through Islamophobia: Global Perspectives, edited by S. Sayyid and A. Vakil. 51-64. London: C. Hurst \& Co.

Appignanesi, Lisa and Sara Maitland (Eds.). 1989. The Rushdie File. London: ICA.

Badinter, Elisabeth. 6 January 2016. La Matinale. Paris: France Inter.

Balibar, Etienne. 1997. "Y a-t-il un 'néo-racisme'?" In Race, nation, classe; les identités ambiguës, edited by Etienne Balibar and Immanuel Wallerstein. 27-41. Paris: la Découverte. 
Bar-On, Tamir. 2013. Rethinking the French New Right: Alternatives to Modernity. London and New York: Routledge.

Barker, Martin. 1982. The new racism: conservatives and the ideology of the tribe. Frederick, Md.: Aletheia Books ; dist. by University Publications of America.

Berkeley, Rob. 2013. "Forward" In The New Muslims, edited by C. Alexander, V. Redclift and A. Hussain. 2. London: Runnymede Trust.

Berretta, Emmanuel. 10 January 2015. "'Charlie Hebdo' - Minute de silence perturbée : I'Éducation nationale recense 70 chahuts." Le Point. http://www.lepoint.fr/politique/emmanuelberretta/charlie-hebdo-minute-de-silence-perturbee-l-education-nationale-recense-70chahuts-10-01-2015-1895466_1897.php

Bever, Lindsey. 4 May 2015. "Pamela Geller, the incendiary organizer of Texas 'prophet Muhammad cartoon contest." Washington Post. https://www.washingtonpost.com/news/morning$\mathrm{mix} / \mathrm{wp} / 2015 / 05 / 04 /$ why-a-woman-named-pamela-geller-organized-a-prophetmuhammad-cartoon-contest/

Beyer, Caroline, and Pauline Verduzier. 20 January 2015. "Charlie Hebdo : ces minutes de silence qui ont dérapé dans les écoles." Le Figaro. http://www.lefigaro.fr/actualitefrance/2015/01/09/01016-20150109ARTFIG00338-ces-minutes-de-silence-qui-ont-derapedans-les-ecoles.php

Buncombe, Andrew. 24 February 2016. "Hijab wearing is 'passive terrorism', says US military publication. "The Independent. http://www.independent.co.uk/news/world/americas/ hijab-wearing-is-passive-terrorism-says-us-military-publication-a6893931.html

Bush, George W. 20 September 2001. Address to a Joint Session of Congress and the American People. edited by Congress of the United States of America. Washington D.C.

Crépon, Sylvain, Alexandre Dézé, and Nonna Mayer, eds. 2015. Les faux-semblants du Front National: Sociologie d'un parti politique. Paris: Sciences Po Les Presses.

Delphy, Christine. 2006. "Antisexisme ou antiracisme? un faux dilemme." Nouvelles Questions Féministes no. 26 (1):59-83.

Delphy, Christine. 2015. Separate and dominate: Feminism and Racism after the War on Terror. London: Verso.

Deltombe, Thomas. 2005. L'islam imaginaire : la construction mediatique de l'islamophobie en France, 1975-2005, Cahiers libres. Paris: La Decouverte.

Ekman, Mattias. 2015. "Online Islamophobia and the politics of fear: manufacturing the green scare." Ethnic and Racial Studies no. 38 (11):1986-2002.

Farris, Sara. 2012. "Femonationalism and the "Regular' Army of Labor Called Migrant Women." History of the Present no. 2 (2):184-199.

Field, Clive D. 2007. "Islamophobia in Contemporary Britain: The Evidence of the Opinion Polls, 1988-2006." Islam and Christian-Muslim Relations no. 18 (4):447-477.

Friedersdorf, Conor. 16 November 2015. "The Dangers of an Anti-Muslim Backlash." The Atlantic. http://www.theatlantic.com/politics/archive/2015/11/jihadists-backlash-erickson/416070/

Gerstenzang, James, and Lisa Getter. 18 November 2001. "Laura Bush Addresses State of Afghan." LA Times. http://articles.latimes.com/2001/nov/18/news/mn-5602

Goldberg, David Theo. 2006. "Racial Europeanization." Ethnic and Racial Studies no. 29 (2):331-364.

Hafner, Joel. 25 February 2016. "Former Ku Klux Klan leader declares support for Donald Trump." USA Today. http://www.usatoday.com/story/news/politics/onpolitics/2016/02/25/davidduke-trump/80953384/

Hajjat, Abdellali, and Marwan Mohammed. 2013. Islamophobie. Comment les élites françaises construisent le "problème musulman". Paris: La Découverte.

Halliday, Fred. 1999. "'Islamophobia' reconsidered." Ethnic and Racial Studies no. 22 (5):892-902.

Harris, Sam. 2004. The End of Faith: Religion, Terror and the Future of Reason. London: Simon and Shuster.

Harris, Sam. 2008. Letter to a Christian Nation. New York: Vintage. 
Harris, Sam, and Maajid Nawaz. 2015. Islam and the Future of Tolerance: A Dialogue. Cambridge: Harvard University Press.

Harris, Sam. 2017. "Winning the War of Ideas: REAL TIME with Bill Maher". Sam Harris Blog. https://www.samharris.org/blog/item/winning-the-war-of-ideas

Horowitz, David. 2004. Unholy Alliance: Radical Islam and the American Left. Washington: Regnery. Houellebecq, Michel. 2015. Soumission. Paris: Flammarion.

Ingulfsen, Inga. 18 February 2016. "Why aren't European feminists arguing against the antiimmigrant right?" Open Democracy. https://www.opendemocracy.net/5050/why-areeuropean-feminists-failing-to-strike-back-against-anti-immigrant-right

Jalabi, Raya. 7 October 2014. "A history of the Bill Maher's 'not bigoted' remarks on Islam." The Guardian. https://www.theguardian.com/tv-and-radio/tvandradioblog/2014/oct/06/billmaher-islam-ben-affleck)

Jihad Watch. Why Jihad Watch 2016. Available from http://www.jihadwatch.org/why-jihad-watch.

Juppé, Alain. 7 January 2015. Alain Juppé invité d'Europe 1 mercredi 7 janvier. In l'interview politique, edited by Jean-Pierre Elkabbach. Paris: Europe 1.

Kazem, Halima. 20 June 2016. "Funding Islamophobia: \$206m went to promoting 'hatred' of American Muslims." The Guardian. https://www.theguardian.com/usnews/2016/jun/20/islamophobia-funding-cair-berkeley-report?CMP=share_btn_tw

Khiabany, Gholam, and Milly Williamson. 2011. "Muslim Women and Veiled Threats: From 'Civilising Mission' to 'Clash of Civilisations'." In Pointing the Finger: Islam and Muslims in the British Media, edited by Julian Petley and Robin Richardson. Oxford: One World.

Klapper, Bradley. 13 January 2015. "US tempers criticism of Muhammad cartoons after Paris attack." Yahoo News. https://www.yahoo.com/news/us-tempers-criticism-muhammad-cartoonsparis-attack-201909001.html?ref=gs

Kolhatkar, Sonali. 10 October 2014. "The Rise of the New, Liberal Islamophobia." Common Dreams. http://www.commondreams.org/views/2014/10/10/rise-new-liberal-islamophobia

Kumar, Deepa. 2012. Islamophobia and the Politics of Empire. Chicago: Haymarket Books.

Kundnani, Arun. 2014. The Muslims are coming: Islamophobia, Extremism and the domestic war on terror. London: Verso.

Laclau, Ernesto. 2005. On populist reason. London: Verso.

Laclau, Ernesto, and Chantal Mouffe. 1985. Hegemony and socialist strategy : towards a radical democratic politics: Verso.

Leconte, Claire. 14 January 2015. "Minute de silence pour 'Charlie Hebdo' refusée par des élèves : on est tous responsables. "L'Obs. http://leplus.nouvelobs.com/contribution/ 1306128-minute-de-silence-pour-charlie-hebdo-refusee-par-des-eleves-on-est-tousresponsables.html

LeMonde.fr. 17 July 2015. "Les actes islamophobes et antisémites en nette progression au premier semestre en France." Le Monde. http://mobile.lemonde.fr/policejustice/article/2015/07/17/les-actes-islamophobes-et-antisemites-en-nette-progression-aupremier-semestre-en-france_4687414_1653578.html

Lentin, Alana, and Gavan Titley. 2011. The Crises of Multiculturalism: Racism in a neoliberal age. London: Zed.

Levin, Brian and Kevin Grisham. 2016. Special Status Report Hate Crime in the United States: 20 State Compilation of Official Data. Center for the Study of Hate and Extremism. San Bernadino: California State University. https://www.documentcloud.org/documents/ 3110202-SPECIAL-STATUS-REPORT-v5-9-16-16.html

Lichtblau, Eric. 17 September 2016. "Hate crimes against American Muslims most since post-9/11 era." New York Times. http://www.nytimes.com/2016/09/18/us/politics/hate-crimesamerican-muslims-rise.html?_r=0

Liogier, Raphaël. 2016. Le mythe de l'islamisation : Essai sur une obsession collective. Paris: Points. 
Maher, Bill. 27 September 2014. "Maher rips liberals over Islam: 'If we're giving no quarter to intolerance, shouldn't we start with honor killers?'” Real Clear Politics.

http://www.realclearpolitics.com/video/2014/09/27/maher_rips_liberals_over_islam_if_we re_giving_no_quarter_to_intolerance_shouldnt_we_start_with_honor_killers.html

Maher, Bill. 2012. "Bill Maher." Wikiquote. https://en.wikiquote.org/wiki/Bill_Maher.

Mark, Michelle. 18 November 2015. "Anti-muslim hate crimes have spiked after every major terrorist attack: after Paris, Muslims speak out against Islamophobia." International Business Times. http://www.ibtimes.com/anti-muslim-hate-crimes-have-spiked-after-every-majorterrorist-attack-after-paris-2190150

Martin, William. 2005. With God On Our Side: The Rise of the Religious Right in America. Danvers: Broadway Books.

Massoumi Narzanin. 2015. Muslim Women, Social Movements and the 'War on Terror'. UK: Palgrave Macmillan.

Merica, Dan. 30 January 2017. "Trump signs executive order to keep out 'radical Islamic terrorists'”. CNN. http://edition.cnn.com/2017/01/27/politics/trump-plans-to-sign-executive-action-onrefugees-extreme-vetting/

Meer, Nasar, and Tariq Modood. 2009. "Refutations of racism in the 'Muslim Question'". Patterns of Prejudice no. 43 (3/4):332-351.

Meer, Nasar. 2014. "Islamophobia and postcolonialism: continuity, Orientalism and Muslim consciousness." Patterns of Prejudice 48 (5):500-515.

Michael, George 2006. The Enemy of My Enemy: The Alarming Convergence of Militant Islam and the Extreme Right. Lawrence: University of Kansas Press.

Modood, Tariq, and Geoffrey Brahm Levey, eds. 2008. Secularism, Religion and Multicultural Citizenship. Cambridge: Cambridge University Press.

Mogul, Priyanka. 23 November 2015. "Paris attacks: Hate crimes against British Muslims soar by 300\% in one week." IB Times. http://www.ibtimes.co.uk/paris-attacks-hate-crimes-againstbritish-muslims-soar-by-300-one-week-1530048

Mondon, Aurelien. 1 September 2016. Defending the indefensible: France, the burkini affair and the further mainstreaming of racism." Open Democracy. https://www.opendemocracy.net/caneurope-make-it/aurelien-mondon/defending-indefensible-france-burkini-affair-and-furthermainstre

Mondon, Aurelien. 2013. The mainstreaming of the Extreme Right in France and Australia: A Populist Hegemony? Aldershot, England; Burlington, VT: Ashgate.

Mondon, Aurelien. 2014. "The Front National in the Twenty-First Century: From Pariah to Republican Democratic Contender?" Modern \& Contemporary France: 1-20. doi: 10.1080/09639489.2013.872093.

Mondon, Aurelien. 2015. "The French secular hypocrisy: the extreme right, the Republic and the battle for hegemony." Patterns of Prejudice no. 49 (4):1-22. doi: 10.1080/0031322X.2015.1069063.

Mondon, Aurelien and Aaron Winter. 28 July 2016. "Islamophobia(s) In the aftermath of the Nice attack." E-International Relations. http://www.e-ir.info/2016/07/28/islamophobias-in-theaftermath-of-the-nice-attack/

Morey, Peter, and Amina Yaqin. 2011. Framing Muslims: Stereotyping and Representation after 9/11. Cambridge Massachusetts: Harvard University Press.

Neiwert, David and Sarah Posner. 21 September 2016. "Meet the horde of neo-nazis, klansmen, and other extremist leaders endorsing Donald Trump". Mother Jones. http://www.motherjones.com/politics/2016/09/trump-supporters-neonazis-white-nationalists-kkk-militias-racism-hate

Norton, Ben. 18 December 2015. "Anti-Muslim hate crimes have tripled in the US since the Paris attacks." Salon. December 18. 
http://www.salon.com/2015/12/18/anti_muslim_hate_crimes_have_tripled_in_the_u_sinc e_the_paris_attacks/

O'Neill, Brendan. 28 November 2015. "Never mind Rhodes - it's the cult of the victim that must fall." Spiked! Online. http://www.spiked-online.com/newsite/article/never-mind-rhodes-its-thecult-of-the-victim-that-must-fall/17762\#.VsGzR_mLTIU

Obeidallah, Dean. 20 February 2017. "Bill Maher's shameful mainstreaming of Yiannopoulos' hate". CNN. http://edition.cnn.com/2017/02/18/opinions/mahers-shameful-mainstreaming-ofyiannopoulos/

Pilkington, Ed. 7 December 2015. "Donald Trump: ban all Muslims entering US." The Guardian. https://www.theguardian.com/us-news/2015/dec/07/donald-trump-ban-all-muslimsentering-us-san-bernardino-shooting

Potok, Mark. 14 November 2016. "Anti-Muslim hate crimes surged last year fueled hateful campaign." Southern Poverty Law Center Hatewatch. https://www.splcenter.org/ hatewatch/2016/11/14/anti-muslim-hate-crimes-surged-last-year-fueled-hateful-campaign

Puar, Jasbir. 2007. Terrorist Assemblages: Homonationalism in Queer Times. Durham and London: Duke University Press.

Rashid, Naaz. 2016. Veiled threats: Representing the Muslim woman in public policy discourses. Bristol: Policy Press.

Runnymede Trust. 1997. Islamophobia: a challenge for us all. London: Runnymede Trust.

Rushdie, Salman. 2008. The Satanic Verses. London: Random House

Said, Edward. 2003. Orientalism. London: Penguin.

Sayyid, S. 2010. "Thinking through Islamophobia." In Thinking Through Islamophobia: Global Perspectives, edited by S. Sayyid and A. Vakil. 1-4. London: C. Hurst \& Co.

Scott, Joan Wallach. 2007. The politics of the veil. Princeton, N.J.: Princeton University Press.

Sherriff, Lucy. 13 January 2015. "LSE student Daniel Wickham's epic tweets expose hypocritical world leaders who attended Charlie Hebdo rally." The Huffington Post.

http://www.huffingtonpost.co.uk/2015/01/13/Ise-student-daniel-wickhams-epic-twittertakedown_n_6461208.html

Southern Poverty Law Center (SPLC). 2001. "Reaping the Whirlwind." Intelligence Report. http://www.splcenter.org/intel/intelreport/article.jsp?pid=296

Southern Poverty Law Center (SPLC) 2016. "Alternative Right." https://www.splcenter.org/fightinghate/extremist-files/ideology/alternative-right

Southern Poverty Law Center (SPLC). 16 December 2016. "Update: 1,094 Bias-Related Incidents in the Month Following the Election." https://www.splcenter.org/hatewatch/2016/12/16/ update-1094-bias-related-incidents-month-following-election

Southern Poverty Law Center (SPLC). 15 February 2017. "Hate groups increase for second consecutive year as Trump electrifies radical right." Intelligence Report : The Year in Hate and Extremism. https://www.splcenter.org/news/2017/02/15/hate-groups-increase-secondconsecutive-year-trump-electrifies-radical-right

Stein, Joel. 15 January 2016. 'Milo Yiannopoulos Is the Pretty, Monstrous Face of the Alt-Right' Bloomberg. https://www.bloomberg.com/features/2016-america-divided/miloyiannopoulos/

Taguieff, Pierre-André. 1994. Sur la Nouvelle droite: jalons d'une analyse critique. Paris: Descartes et Cie.

Taras, Raymond. 2013.“'Islamophobia never stands still': race, religion, and culture. " Ethnic and Racial Studies no. 36 (3):417-433.

Tayler, Jeffrey. 13 December 2015. “Follow Bill Maher's lead, not Donald Trump: There's a way to critique ideology behind religion without resorting to hate." Salon.

http://www.salon.com/2015/12/13/follow_bill_mahers_lead_not_donald_trump_theres_a_ way_to_critique_ideology_behind_religion_without_resorting_to_hate/?utm_source=faceb ook\&utm_medium=socialflow 
Tevanian, Pierre. 2005. Le voile médiatique. Un faux débat : " l'affaire du foulard islamique ". Paris: Editions Raisons d'Agir.

Tyrer, David. 2010. "Flooding the eEmbankments': Race, bio-politics and sovereignty." In Thinking Through Islamophobia: Global Perspectives, edited by S. Sayyid and A. Vakil. 93-110. London: C. Hurst \& Co.

Werbner, Pnina. 2013. "Folk devils and racist imaginaries in a global prism: Islamophobia and antiSemitism in the twenty-first century." Ethnic and Racial Studies no. 36 (3):450-467.

Winter, Aaron. 2010. "American Terror: From Oklahoma City to 9/11 and After." In Discourses and Practices of Terrorism: Interrogating Terror, edited by B. Brecher, M. Devenney and A. Winter. 156-176. Abingdon: Routledge.

Winter, Aaron. 2014. "My enemies must be friends: The American extreme right, conspiracy theory, Islam and the Middle East." In Conspiracy Theories in the Middle East and the United States: A Comparative Approach, edited by M. Reinkowski and M. Butter. 35-58. Berlin: de Gruyter. Zemmour, Eric. 2014. Le Suicide français. Paris: Albin Michel.

Zempi Irene and Chakraborti, Neil. 2014. Islamophobia, Victimisation and the Veil. London: Palgrave Macmillan.

Yiannopoulos, Milo. 15 June 2016. “Milo in Orlando: Gays, like Jews, should say 'never again!'." Breitbart. http://www.breitbart.com/milo/2016/06/15/milo-orlando-gays-say-never/

Yiannopoulos, Milo. 12 October 2016. "Full Text: Milo at WCU on Feminism and Islam, the Unholy Alliance." Breitbart. http://www.breitbart.com/milo/2016/10/12/full-text-milo-wcufeminism-islam-unholy-alliance/

\footnotetext{
${ }^{1}$ The report elaborated eight 'distinctions' which could lead to the unfair treatment of the Muslim community, including that Islam is seen as: a monolithic bloc, static and unresponsive to change; lacking values in common with other cultures; as inferior to the West; as barbaric, irrational, primitive, and sexist; as violent, aggressive, threatening, supportive of terrorism.

${ }^{2}$ See for example this statement from the National Alliance's Billy Roper: 'The enemy of our enemy is, for now at least, our friends. We may not want them marrying our daughters, just as they would not want us marrying theirs. We may not want them in our societies, just as they would not want us in theirs .... But anyone who is willing to drive a plane into a building to kill jews is alright by me. I wish our members had half as much testicular fortitude' (SPLC 2001).

${ }^{3}$ Falwell declared: 'I really believe that the pagans, and the abortionists, and the feminists, and the gays and the lesbians who are actively trying to make that an alternative lifestyle ...I point the finger in their face and say, 'You helped this happen' (SPLC 2001).

${ }^{4}$ The US State Department issued the following statement following the January 2015 attack: 'Regardless of what anyone's personal opinion is, and I know there are very heated personal opinions about this, we absolutely support the right of Charlie Hebdo to publish things like this ...That's what happens in a democracy. Period.'
} (Klapper 13 January 2015)

${ }^{5} \mathrm{~A}$ similar trend has also been witnessed in the UK. Spiked!'s campaigns in which anti-racists, feminists and LGBT activists, 'safe spaces', 'no platforming', the Rhodes Must Fall campaign, the attack on Charlie Hebdo and ISIS's destruction of Palmyra, are placed on the same continuum, if not equated, based on a shared inclination towards particularism, being 'offended' and censorship (O'Neill 28 November 2015) Not only are anti-racists, feminists and LBGT activists seen as abusing the liberal rights and equalities bestowed upon them by progressive 
liberalism, through their particularism, identity politics, political correctness, anti-racism, anti-imperialism and multiculturalism, they invited Muslims and their illiberalism and intolerance into 'Our' society, and continue to defend them. 